\title{
Uklad aktywnego sterowania zawieszeniem pneumatycznym pojazdów szynowych
}

\begin{abstract}
$W$ artykule omówiono aktualny zakres prac zrealizowanych $w$ ramach projektu celowego nr. 6ZR6 2009C/07185 „System zawieszenia pneumatycznego wagonów osobowych, zespołów trakcyjnych i lekkich pojazdów szynowych z układem aktywnego sterowania". Przedstawiono i uzasadniono celowość wprowadzenia w przyszłości mikroprocesorowego sterowania zawieszeniem pneumatycznym przeznaczonego dla pojazdów szynowych. Opisano badane sprężyny pneumatyczne oraz zaprezentowano zbudowane w IPS Tabor stanowisko do ich wszechstronnych badań.
\end{abstract}

\section{Opis stanu dotychezasowego}

Dotychczasowe układy usprężynowania pneumatycznego pojazdów szynowych składają się z siłowników pneumatycznych i układu sterowania ciśnieniem $\mathrm{w}$ zawieszeniu pneumatycznym (rys.1) opartym na tak zwanych zaworach pneumatycznych poziomu.

Zawory te zasilane są sprężonym powietrzem z przewodu zasilającego najczęściej poprzez układ ograniczający maksymalne ciśnienie w tym zawieszeniu (np. poprzez reduktor ciśnienia). Zawór poziomu jest zaworem napełniająco-opróżniającym sterowanym położeniem dźwigni połączonej mechanicznie $\mathrm{Z}$ wózkiem poprzez regulacyjną śrubę rzymską z dwoma przegubami kulistymi. Zawór posiada pewną stała histerezę i zmienną zdolność napełniania i opróżniania $\mathrm{w}$ funkcji wychylenia kątowego jego ramienia (rys. 2).

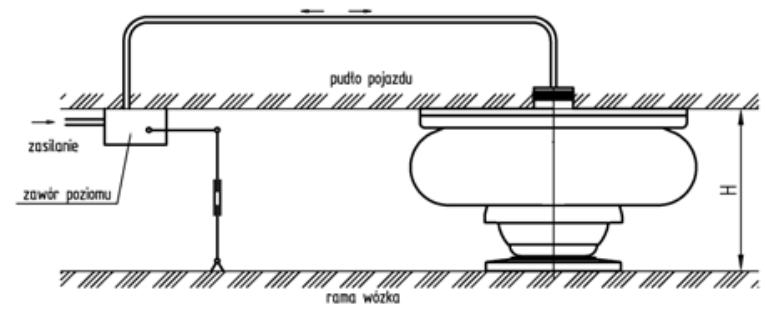

Rys.1 Dotychczas stosowany system sterowania

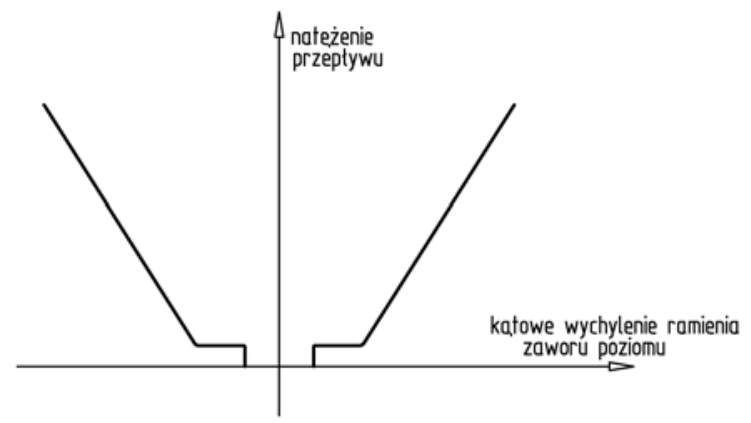

Rys. 2 Histereza i przebieg zmienności natężenia przepływu zaworka napełniającego i opróżniającego zaworu poziomu $\mathrm{W}$ funkcji wychylenia kątowego jego ramienia
Zawór poziomu montowany jest na podwoziu pojazdu i poprzez ramię dźwigni oraz regulacyjną śrubę rzymską połączony jest z ramą wózka. Dzięki temu po zasileniu zaworu poziomu sprężonym powietrzem następuje napełnianie sprężyny pneumatycznej (siłownika pneumatycznego) do momentu aż nie osiagnie ona zadanej (wyregulowanej długością śruby rzymskiej) wysokości. Zmiana obciążenia pudła prowadzi do zmiany wysokości sprężyny i tym samym do jej napełniania lub opróżniania przez zawór poziomu sterowany położeniem kątowym ramienia dźwigni. Dzięki temu bez względu na obciążenie pojazdu poziom podłogi pojazdu znajduje się na stałej wysokości względem główki szyny, z dokładnością wynikająca z histerezy ugięcia niezbędnej do otwarcia zaworka napełniającego lub opróżniającego.

2. Układ mikroprocesorowego sterowania ciśnieniem zawieszenia pneumatycznego

Docelowe sterowanie mikroprocesorowe zawieszenia pneumatycznego pojazdu składać się będzie $\mathrm{Z}$ czujnika ultradźwiękowego lub laserowego umieszczonego wewnątrz sprężyny pneumatycznej do pomiaru jej wysokości, sterownika zawieszenia (CPU), zaworu elektropneumatycznego napełniającego i opróżniającego sprężynę, a w przyszłości również innych czujników mierzących stan pojazdu podczas jazdy (rys. 3).

Sterowanie mikroprocesorowe umożliwi sterowanie wysokością sprężyny tak by niezależnie od wartości obciążenia sprężyny (pojazdu) jej wysokość pozostawała stała. Ponadto umożliwi wyeliminowanie zużywających się mechanicznych elementów zawieszenia, takich jak zawór poziomu sterowany ramieniem dźwigni oraz śruby rzymskiej z przegubami kulistymi. Dodatkowo dzięki zastoso-waniu mikroprocesorowego sterowania ciśnieniem w sprężynach pneumatycznych zawieszenia pojazdu szynowego $\mathrm{z}$ elektrycznym pomiarem wysokości sprężyny, układ może zapewniać podczas eksploatacji: 


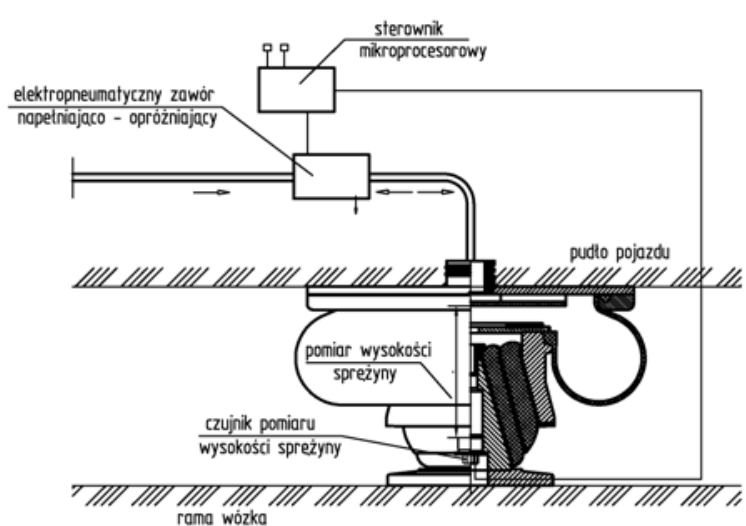

Rys. 3. Ogólny układ sprężyny pneumatycznej sterowanej mikroprocesorowo

- zmienną regulowaną wysokość podłogi pojazdu (możliwość automatycznego dopasowania się wysokości pudła do zróżnicowanej wysokości peronów),

- realizację sztucznej wymuszonej przechyłki pojaz$\mathrm{du} \mathrm{w}$ łuku w funkcji zmierzonego przyspieszenia dośrodkowego (poprawa komfortu i możliwość zwiększenia prędkości maksymalnej pojazdu w łuku),

- możliwość wprowadzenia zmiennej histerezy zawieszenia pneumatycznego ( rys.4) w zależności od parametrów dynamicznych zmierzonych podczas jazdy pojazdu np. prędkości (rys.5) czy przyspieszeń (rys.6). Na przykład dla prędkości $\mathrm{V}=0 \mathrm{~km} / \mathrm{h}$ histereza może wynosić $\pm 1 \mathrm{~mm}$, a dla innych prędkości może być regulowana i zmieniać się np proporcjonalnie do prędkości.

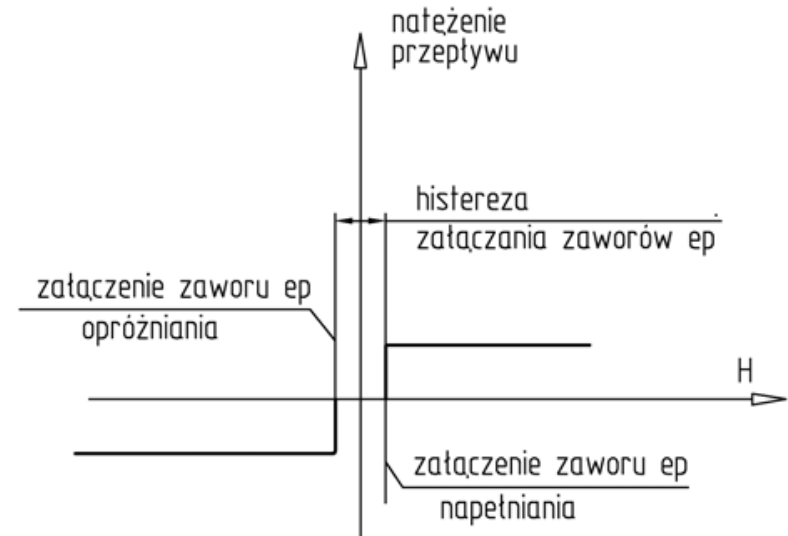

Rys.4. Histereza i charakterystyka natężenia przepływy powietrza przez elektrozawór sterowany mikroprocesorowo

3. Elementy zawieszenia pneumatycznego pojazdu W ramach projektu opracowano dwa siłowniki (sprężyny) pneumatyczne pokrywające zapotrzebowanie obciążeń stosowanych $\mathrm{w}$ pojazdach szynowych. Zgodnie z podstawowymi parametrami charakteryzującymi przedmiot wdrożenia opracowane siłowniki powinny pokryć zapotrzebowanie obciążenia piono-

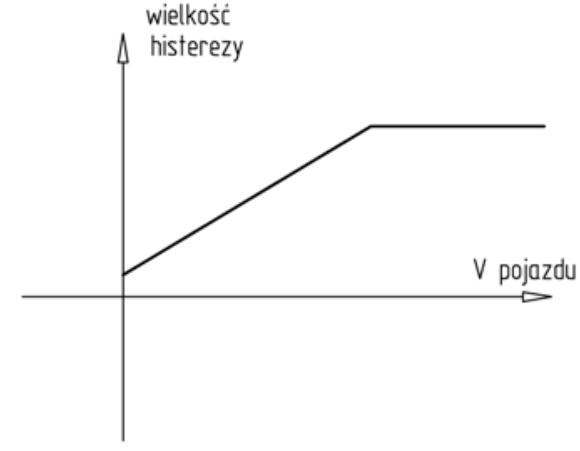

Rys. 5. Wielkość histerezy w funkcji prędkości pojazdu

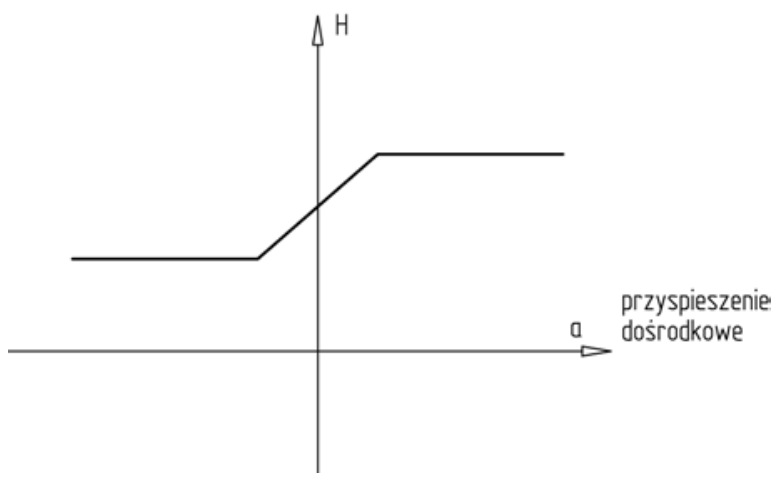

Rys. 6. Zmiana wysokości sprężyny pneumatycznej w funkcji przyspieszenia dośrodkowego

wego co najmniej w zakresie $8-16$ ton masy pudła pojazdu przypadającego na jeden siłownik (sprężynę). W związku z powyższym do realizacji przyjęto dwa rodzaje sprężyn pneumatycznych: o średnicy około $600 \mathrm{~mm}$ i o średnicy $800 \mathrm{~mm}$ (rys. 7).
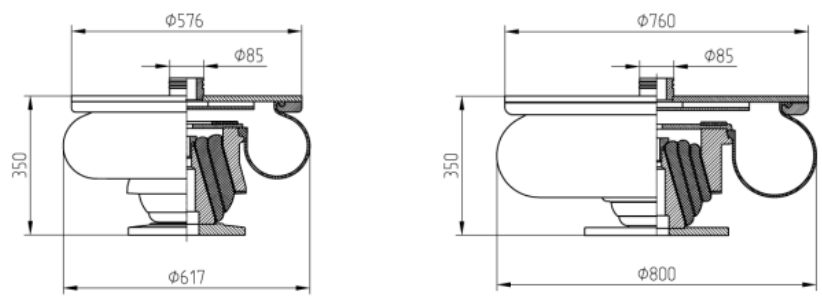

Rys. 7. Widok ogólny przyjętych do realizacji sprężyn pneumatycznych

Sprężyna o średnicy $600 \mathrm{~mm}$ (dla lekkich pojazdów szynowych) może realizować następujące obciążenia:

-przy ciśnieniu $200 \mathrm{kPa}$ około $5650 \mathrm{~kg}$,

- przy ciśnieniu $400 \mathrm{kPa}$ około $11300 \mathrm{~kg}$. Sprężyna o średnicy $800 \mathrm{~mm}$ może realizować następujące obciążenia:

- przy ciśnieniu $200 \mathrm{kPa}$ około $10000 \mathrm{~kg}$,

- przy ciśnieniu $400 \mathrm{kPa}$ około $20000 \mathrm{~kg}$.

Zakłada się, że dla obu sprężyn pneumatycznych następujące podstawowe parametry:

- maksymalne dopuszczalne ciśnienie $700 \mathrm{kPa}$,

- maksymalne ciśnienie robocze $500 \mathrm{kPa}$,

-minimalne ciśnienie robocze $100 \mathrm{kPa}$,

-maksymalne ugięcie pionowe około $60 \mathrm{~mm}$,

-maksymalne odbicie pionowe około $160 \mathrm{~mm}$ 
W ramach projektu opracowano dokumentacje techniczną sprężyny pneumatycznej o średnicy około $600 \mathrm{~mm}$ i dokumentację techniczną sprężyny pneumatycznej o średnicy $800 \mathrm{~mm}$ spełniające wyżej podane wymagania. W skład dokumentacji obu sprężyn pneumatycznych wchodzą „miechy pneumatyczne" o wyżej wymienionych średnicach i zunifikowane specjalne sprężyny gumowo-metalowe oparcia awaryjnego. Sprężyny te wykorzystywane są w pojeździe w przypadku awaryjnego sprężystego oparcia pudła na ramie wózka, na skutek awarii układu zawieszenia pneumatycznego w pojeździe. Unifikacja sprężyn gumowo-metalowych polega na tym, że sprężyny dla obu średnic miecha składają się z dwu zunifikowanych wymiarowo elementów gumowych. Sprężyna gumowo-metalowa sprężyny pneumatycznej o średnicy $600 \mathrm{~mm}$ składa się tylko z dwu elementów gumowych zwulkanizowanych ze stożkowymi tulejami stalowymi, a sprężyna gumowo-metalowa sprężyny pneumatycznej o średnicy 800 mm składa się z trzech elementów gumowych prz czym dwa $\mathrm{z}$ nich są identyczne jak w sprężyni pneumatycznej o średnicy $600 \mathrm{~mm}$.

Wyżej wymieniona dokumentacja techniczna został opracowana $\mathrm{w}$ oparciu o wymagania zawarte $\mathrm{I}$ aktualnie obowiązującej normie PN-EN 13597 „Kc lejnictwo - Gumowe elementy zawieszenia - Gumc we przepony sprężyn zawieszenia pneumatycznego listopad 2003 (norma europejska: EN13597:2003 Railway applictions - Rubber suspension componen1 - Rubber diaphragms for pneumatic suspensio springs").

W ramach projektu firma „Intergum” opracowal dokumentację oprzyrządowania, form i technologi wytwarzania sprężyn pneumatycznych, w oparciu dokumentację techniczną sprężyn opracowaną prze IPS Tabor. Wykonane przez firmę „Intergum oprzyrządowanie i formy posłużyły do wykonani prototypowych sprężyn pneumatycznych do przew dzianych $\mathrm{w}$ projekcie badań, które są przeprc wadzane na opracowanym i wykonanym przez IP stanowisku do badań.

$\mathrm{W}$ ramach realizowanego zadania wytypowano $\mathrm{d}$ badań układu: czujnik pomiaru odległości, dobran sterownik mikroprocesorowy do sterowania zawie szeniem pneumatycznym oraz wytypowano zawć elektropneumatyczny napełniająco-opróż-niający d badań układu i opracowano niezbędne oprogramc wanie do przeprowadzenia prób na stanowisk badawczym. Dla docelowego układu wytypowan ciśnieniowy (do 6 bar) czujnik ultradźwiękowy d pomiaru wysokości UP56-211118 firmy Sic mocowany wewnątrz sprężyny pneumatyczne, natomiast do badań zakupiono czujnik ultradźwiękowy MIKROSONIC typ mic+35/IU/TC firmy Introl. Czujnik ten podczas badań jest zamocowany pomiędzy płytami sprężyny pneumatycznej. Do badań wytypowano sterownik mikroprocesorowy RSSA 8iA 10o24 10i24 wyprodukowany przez IPS Tabor i zawór napełniająco-opróżniający 7ZH 510000-1-00 również produkcji IPS Tabor.

Stanowisko do badań zawieszenia opracowano w zakresie funkcjonalnym oraz $\mathrm{w}$ celu możliwości zrealizowania badań zgodnie $\mathrm{z}$ wymaganiami określonych w normie PN-EN 13597 „Kolejnictwo Gumowe elementy zawieszenia - Gumowe przepony sprężyn zawieszenia pneumatycznego", których celem jest potwierdzenie możliwości spełnienia przez wykonane zawieszenie pneumatyczne postawionych założeń.

\section{Stanowisko do badań sprężyn pneumatycznego zawieszenia}

Na rys. 8 przedstawiono projekt stanowiska do badań badań gumowych elementów zawieszenia zgodnie $\mathrm{z}$ normą PN-EN 13597 oraz aktywnego układu zawieszenia pneumatycznego.
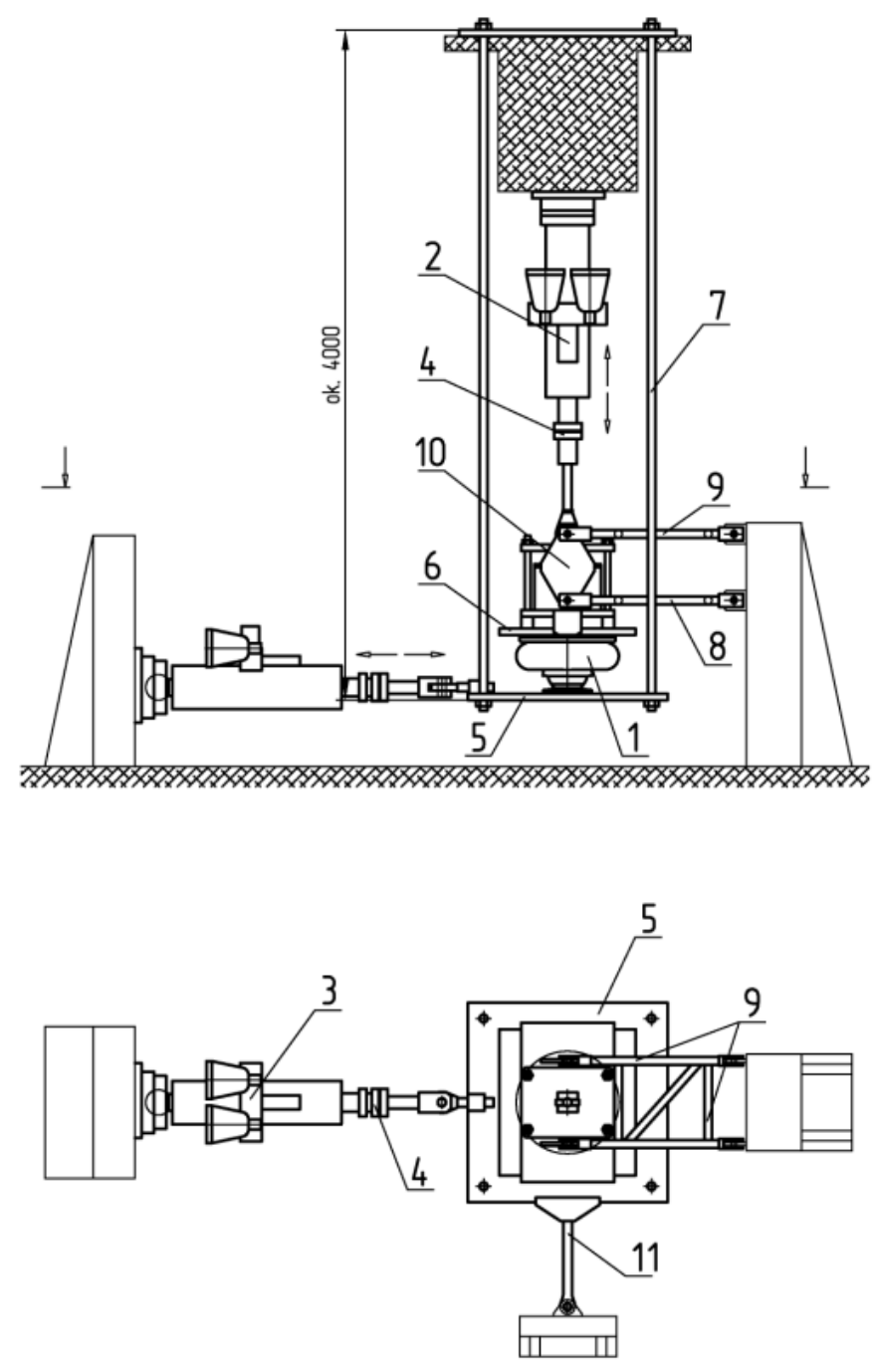

Rys. 8. Stanowisko do badań sprężyn pneumatycznych 
Stanowisko umożliwia wytworzenie wymaganych obciążeń i ugięć $w$ kierunku pionowym i poprzecznym a także umożliwia wzajemne przemieszczenia promieniowe i obrót podstaw sprężyny.

Do realizacji obciążeń pionowych i poprzecznych służą dwa siłowniki serwo-hydrauliczne (2 i 3) typu PL $160 \mathrm{~N}$ firmy Instron o zakresie $\pm 160 \mathrm{kN}$ i skoku $\pm 125 \mathrm{~mm}$. Przegubowo zamontowany siłownik poziomy (3) umożliwia realizację przemieszczeń poprzecznych podstawy sprężyny oraz przy w przypadku połączenia dolnej płyty (5) z cięgłem (11) zapewnia jej obrót (rys. 11) - wymagany dodatkowo programem prób .

Obciążenia osiowe i poprzeczne mierzone są dynamometrami tensometrycznymi (4) typu PM 160GL2 firmy Instron o zakresie $\pm 160 \mathrm{kN}$ współpracującymi ze wzmacniaczami pomiarowymi serii 8800 .

W celu zapewnienia warunków pracy odpowiadającym pracy sprężyn pneumatycznych zamon-towanych pomiędzy pudłem i ramą wózków na pojazdach szynowych, oraz w celu spełnienia wymagań w/w normy podczas badań gumowych elementów zawieszenia, płytę dolną (5), na której zamontowano sprężynę (1) zawieszono na wieszakach (7) o długości około czterech metrów. Zapewnia to zachowanie wystarczającej równoległości płyty dolnej do płyty górnej (6) w trakcie realizacji obciążeń i przemieszczeń poprzecznych pomiędzy płytami, wywołanymi siłownikiem (3).

Natomiast dla zachowania równoległego położenia płyty górnej względem płyty dolnej podczas obciążeń i przemieszczeń w kierunku pionowym i poprzecznym (wywołanych podczas badań siłownikiem pionowym 2 i siłownikiem poziomym 3), płyte górną sprężyny pneumatycznej połączono $\mathrm{z}$ dwoma płytami bocznymi (10) i z równoległymi sztywnymi wahaczami (8 i 9) stanowiącymi wspólnie czworobok przegubowy.

Ogólny widok zrealizowanego stanowiska do badań sprężyn pneumatycznych przedstawiono na rys.9 i 10.

$\mathrm{Na}$ stanowisku można też dokonywać pomiarów przemieszczeń w kierunku pionowym i poziomym, pomiarów ciśnienia w sprężynie pneumatycznej, pomiarów wysokości sprężyny oraz rejestracji tych parametrów w funkcji czasu. Na stanowisku można również przebadać układ mikroprocesorowego sterowania wysokością sprężyny pneumatycznej, którego schemat blokowy pokazano na rys. 12 .

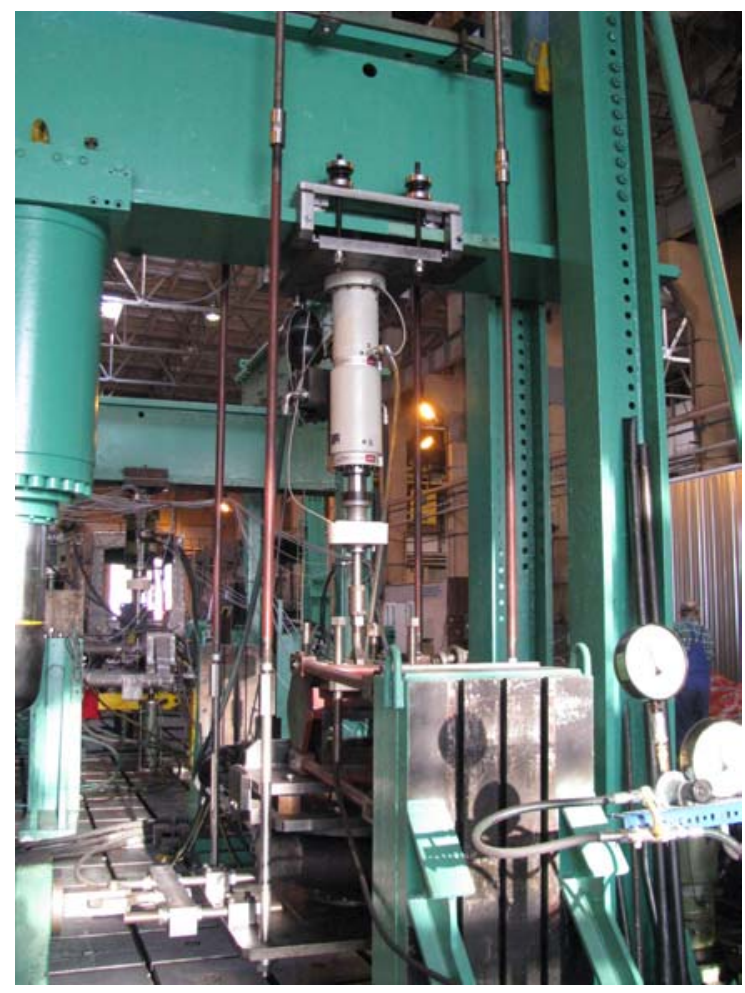

Rys. 9. Ogólny widok stanowiska do badań sprężyn pneumatycznych

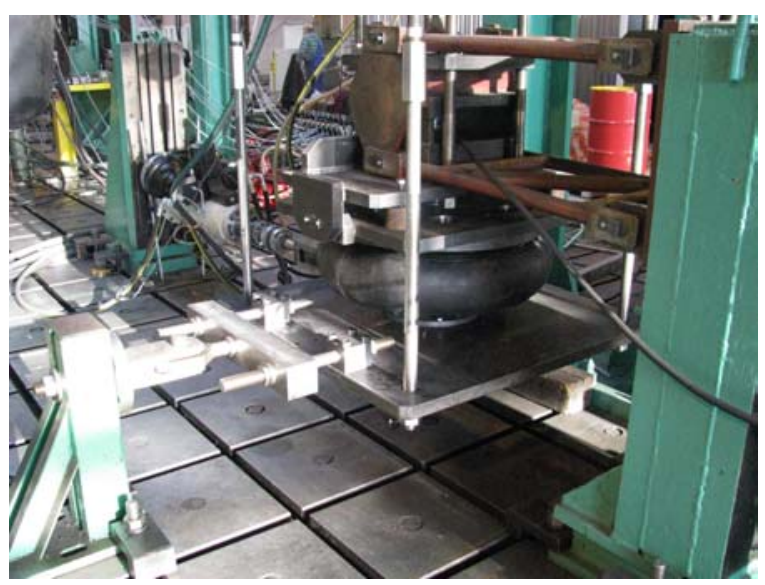

Rys. 10. Fragment stanowiska badawczego z badaną sprężyną pneumatyczną

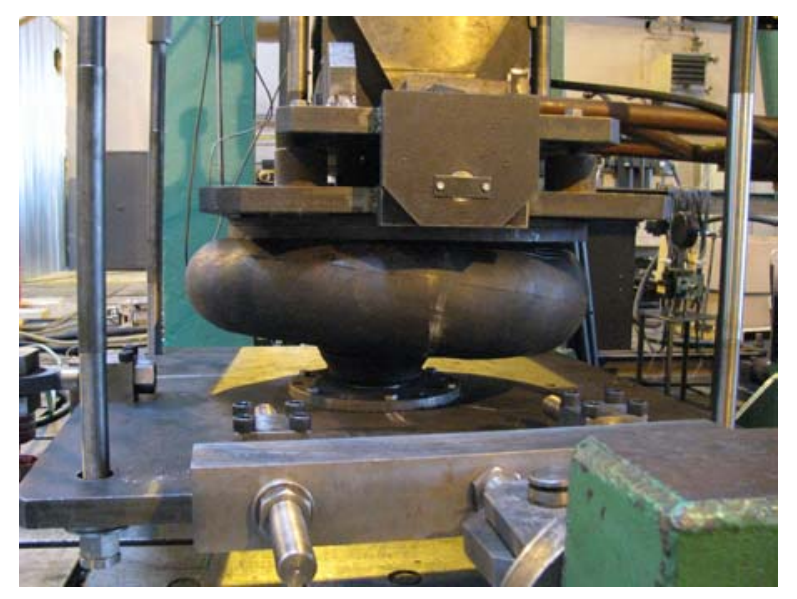

Rys. 11. Sprężyna w trakcie badań oddziaływania na nią przemieszczeń poprzecznych i obrotowych 


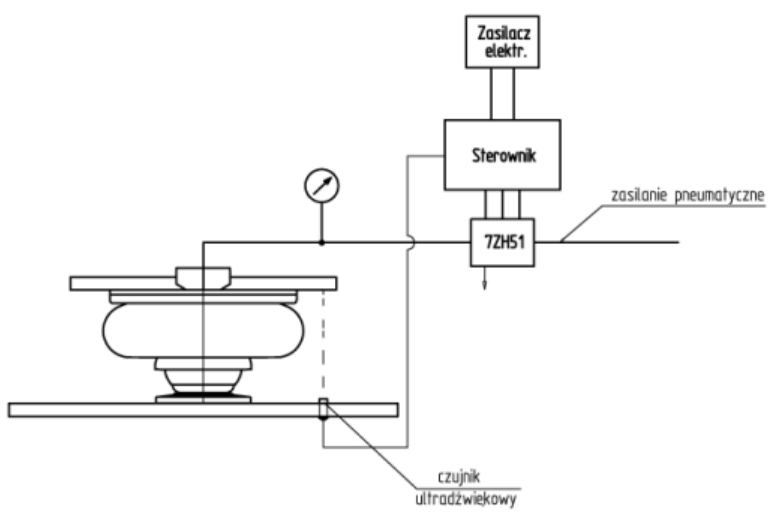

Rys.12. Układ mikroprocesorowego sterowania wysokością sprężyny pneumatycznej na stanowisku badawczym

\section{Zakończenie}

Na przedstawionym stanowisku badawczym przebadano już sprężynę pneumatyczną o średnicy $800 \mathrm{~mm}$ zgodnie $\mathrm{z}$ wymaganiami zawartymi w normie PN-EN 13597 oraz wykonano część zaplanowanych prób z zastosowaniem sterowania mikroprocesorowego. Wykonana w ramach wymienionego na wstępie projektu celowego sprężyna pneumatyczna o średnicy $800 \mathrm{~mm}$ spełniła wymagania wyżej wymienionej normy. Badania będą kontynuowane w 2012 roku i obejmą także sprężynę o średnicy około $600 \mathrm{~mm}$.

Przeprowadzenie badań w całym zakresie i dla obydwu rodzajów sprężyn oraz analiza uzyskanych wyników pozwoli na ostateczną, całościową ocenę badanego układu aktywnego sterowania zawieszeniem pneumatycznym dla pojazdów szynowych. 